\title{
POTENSI JENIS-JENIS IKAN AIR TAWAR KONSUMSI MASYARAKAT ALIRAN SUNGAI DIGOEL, KABUPATEN BOVEN DIGOEL, PAPUA, DAN BEBERAPA LANGKAH PENGELOLAANNYA
}

\author{
Lexy K. Rarung*) dan Silvester B. Pratasik ${ }^{* *}$ \\ *) Staf Pengajar pada Program Studi Sosial Ekonomi Perikanan, \\ ${ }^{* *}$ Staf Pengajar pada Program Studi manajemen Sumberdaya Perairan \\ Fakultas Perikanan dan IImu Kelautan. UNSRAT. Manado 95115.
}

\begin{abstract}
Rarung, L.K. and S.B. Pratasik. 2010. Potential Types of Freshwater Fish

Public Consumption in Digoel Watershed Society, Digoel District, Papua, and Some Steps Their Management. Jurnal Perikanan dan Kelautan. Vol VI (1): 41-45.
\end{abstract}

This study aimed at providing information on freshwater fish living in Digoel River, Boven Digoel Regency, Papua, edible for local people and some management options. Data were collected from observing the fishing activities and Tanah Merah market, and through personal interviews as well. Results showed that there were about 23 species of native and introduced fish living in the Digoel River. Native fish population is decreasing as a result of forest clear cut, pollution, irrational fishing and predation. Therefore, management actions should be taken.

Keywords: freshwater fish, fishing activities, population, management.

\section{PENDAHULUAN}

Kabupaten Boven Digoel, Propinsi Papua adalah salah satu wilayah kabupaten pemekaran yang memiliki daerah aliran sungai yang cukup strategis, memiliki potensi sumberdaya perikanan yang besar. Hal tersebut disebabkan karena daerah ini masih tergolong daerah yang belum banyak terjamah oleh exploitasi sumberdaya perikanan, khususnya perikanan perairan tawar. Kondisi ini menyebabkan daerah aliran sungai perairan kabupaten ini menyimpan berbagai kekayaan hayati perairan umum, seperti ikan dan berbagai jenis sumberdaya perikanan lainnya, yang memungkinkan terbukanya peluang berbagai bentuk pemanfaatan sumberdaya perikanannya maupun media perairan tawar sebagai wadah pengembangan sumberdaya perikanan. Pemanfaatan sumberdaya perikanan dapat meliputi pemanfaatan untuk konsumsi masyarakat, pengembangan ilmu pengetahuan maupun pengembangan usaha budidaya perikanan air tawar.

Secara ekologis, daerah aliran sungai tidak dapat berdiri sendiri karena bergantung pada keseimbangan antara berbagai elemen alam yang berinteraksi membentuk ekosistem sungai yang unik, seperti hutan dan daratan sekitarnya, sehingga keberadaan sumberdaya perairannya juga sangat dipengaruhi oleh perubahan-perubahan ekosistem sekitarnya. Hal ini penting dalam mempersiapkan pengembangan daerah ini dalam konsep pengelolaan berkelanjutan untuk melindungi lingkungan perairan terhadap ancaman perusakan sumberdaya perairan serta habitatnya.

Penelitian ini difokuskan pada penelusuran jenis-jenis ikan air tawar konsumsi masyarakat serta mengamati perilaku nelayan dalam memanfaatkan sumberdaya perikanannya. Hasil penelitian ini diharapkan dapat menjadi arahan pengelolaan sumberdaya perikanan perairan tawar, baik sebagai kawasan lindung (daerah pemijahan), kawasan penangkapan, budidaya maupun kawasan tertentu sehingga 
dapat meningkatkan lingkungan yang lestari dan kondusif terhadap pengembangan kesejahteraan masyarakat secara berkelanjutan.

\section{METODOLOGI PENELITIAN}

Pengambilan sampel dilakukan pada daerah aliran sungai Digoel, yang meliputi sungai Digoel, sungai Mapi, sungai Mandobo, muara sungai Kaoh dan sungai Muyu. Pengamatan dilakukan di daerah-daerah dimana terdapat kegiatan penangkapan ikan di sungai dengan memanfaatkan alat tangkap ikan yang biasa dipakai masyarakat setempat dan melakukan wawancara langsung dengan masyarakat yang hidup di sekitar daerah aliran sungai. Pasar lokal Tanah Merah juga dikunjungi sebagai sumber informasi lapangan, disamping penggunaan data sekunder dan penelusuran pustaka.

Semua sampel diawetkan dalam larutan formalin $40 \%$ dan dibawa ke Laboratorium Hidrobioekologi, Fakultas Perikanan dan IImu Kelautan, Universitas Sam Ratulangi Manado, untuk melakukan identifikasi jenis. Penentuan jenis dilakukan menggunakan petunjuk Allen (1991) dan Kottelat dkk (1993).

\section{HASIL DAN PEMBAHASAN}

Studi ini menemukan sebanyak 23 spesies ikan yang mendiami daerah aliran sungai Digoel yang biasanya dimanfaatkan masyarakat sebagai ikan konsumsi, seperti ikan duri (Arius leptaspis), lele ekor cagak ( $A$. carinatus), lele hitam (Clarias batrachus), ikan Sembilan (Porochillus meraukensis), gabus rawa (Oxyleotris herwardenii), gabus Toraja (Channa striata), nilem (Barbodes gonionatus), belanak (Mugil cephalus), arwana (Scleropages jardinii), kakap putih (Lates calcarifer), kakap hitam (Hephaestus roemeri), kakap kembang (Glossamia sandei), ikan tawar (Nibea saldado), gourame (Osphronemus goramy), mas (Cyprinus carpio), sumpit (Toxotes chatareus), koprasi (Paraambassis gulliveri), betik (Anabas testudineus), tulangtulang (Thryssa rastrosa), mata bulan (Megalop cyprinoides), ikan kaca (Kurtus gullveri), mujair (Oreochromis mossambicus) dan nila (Oreochromis niloticus). Jenis-jenis ikan ini terdiri dari dari ikan asli Papua dan hasil program introduksi ikan di masa lampau.

Jenis- jenis ikan yang ditangkap nelayan didominasi oleh ikan duri, diikuti oleh ikan gabus Toraja, jenis-jenis kakap air tawar, gourame dan ikan mas. Dari semua jenis ikan yang tertangkap, terdapat beberapa jenis ikan introduksi yang telah beradaptasi dan berkembang baik di daerah ini, seperti gourame (O. Goramy), gabus Toraja (C. Striata), Mujair (O. Mossambicus), nila (O. Niloticus) dan ikan mas (C. Carpio). Kehadiran ikan-ikan ini, terutama gabus Toraja yang bersifat kompetitor dan predator, telah menimbulkan ancaman serius bagi kelangsungan hidup spesies ikan asli lokal. Kasus terancam punahnya gabus rawa di danau Sentani merupakan salah satu contoh dampak dari program introduksi di masa lampau. Dominasi hasil tangkapan spesies-spesies ikan tertentu yang ditemukan dalam penelitian ini juga mencerminkan menurunnya populasi spesies ikan asli dan endemik Papua, seperti koloso/arwana dan beberapa jenis ikan pelangi, yang memiliki nilai ekonomis yang sangat tinggi sebagai jenis ikan hias. Menurut Allen (1991), perairan umum pulau Papua secara keseluruhan memiliki sekitar 330 spesies ikan berukuran besar dan kecil yang dapat dimanfaatkan sebagai komoditi ikan konsumsi maupun ikan hias, dimana 100 spesiesnya berasal dari jenis-jenis yang hidup di perairan estuari.

Meskipun gabus toraja merupakan salah satu spesies ikan introduksi yang tergolong ikan predator/pemangsa yang telah mengancam jenis-jenis ikan asli, spesies ikan ini juga telah menjadi jenis ikan konsumsi masyarakat kabupaten Boven Digoel dan setiap hari dijual di pasar-pasar dalam jumlah cukup besar. Oleh karena itu, gabus toraja dapat dikatakan telah memiliki nilai ekonomis dalam memenuhi 
kebutuhan protein hewani masyarakat. Di satu pihak, sumberdaya ikan gabus toraja dapat dimanfaatkan sebagai salah satu komoditi perikanan yang bernilai ekonomis, dan di lain pihak, populasi gabus toraja, dapat dikontrol untuk menunjang kelangsungan hidup populasi jenis-jenis ikan asli.

Ikan-ikan yang tertangkap dan dijual di pasar Digoel rata-rata berukuran besar, artinya ikan-ikan yang tertangkap telah berumur dewasa. Hal ini didukung oleh penggunaan alat tangkap ikan yang sangat selektif. Rata-rata alat tangkap yang digunakan adalah jenis jaring insang bermata jaring 4 inci. Ukuran ikan yang rata-rata besar serta cara penangkapan yang ramah lingkungan ini secara kualitatif menunjukkan bahwa stok sumberdaya perikanan air tawar Kabupaten Boven Digoel masih sangat berlimpah. Meskipun demikian, tidak tersedianya data tahunan hasil tangkapan ikan yang memadai, maka secara kuantitatif kondisi stok ikan tidak dapat dihadirkan dalam hasil penelitian ini. Kondisi ini juga ditunjang oleh rendahnya tingkat eksploitasi sumberdaya perikanan di perairan umum. Pengamatan lapangan menujukkan bahwa hanya beberapa unit jaring insang yang dioperasikan di bagian tepi sungai, meskipun terdapat peningkatan jumlah alat tangkap dari tahun ke tahun. Umumnya penangkapan ikan dilakukan untuk kebutuhan konsumsi rumah tangga, terutama daerah-daerah yang belum memiliki prasarana transportasi yang baik dan terisolir dari pusat pemasaran, seperti distrik Mapi, Subur, Kombut dan lain-lain, serta masih rendahnya tingkat konsumsi ikan di kabupaten Boven Digoel sebagai sumber protein hewani (Anonymous, 2007).

Meskipun demikian, hasil wawancara menunjukkan bahwa populasi ikan di aliran sungai Digoel telah mengalami penurunan. Hal ini didukung oleh waktu tunggu pengoperasian jaring sekarang lebih lama dan jumlah tangkapan lebih sedikit dibandingkan dengan kondisi masa lalu. Pengamatan lapangan juga menunjukkan bahwa hasil tangkapan per satuan unit jaring insang rendah. Oleh karena itu, para penangkap ikan biasanya harus menampung hasil tangkapannya dalam keadaan hidup sebelum dibawa untuk dijual di pasar Digoel. Kenaikan jumlah armada penangkapan ikan dalam bentuk jumlah perahu tanpa motor dan perahu motor tempel juga tidak memberikan kontribusi yang nyata dalam peningkatan hasil tangkapan ikan nelayan, karena perahu-perahu motor, yang biasanya dipakai dalam operasi penangkapan ikan, juga digunakan sebagai sarana transportasi air untuk mengangkut penumpang.

Hal ini menunjukkan bahwa dengan berjalannya waktu, maka meningkatnya kegiatan eksploitasi sumberdaya perikanan serta adanya degradasi lingkungan perairan akibat aktivitas manusia, seperti penebangan hutan dan pertambangan telah mempengaruhi besarnya ketersediaan sumberdaya perikanan di wilayah ini. Pengamatan lapangan jelas menunjukkan bahwa kegiatan penebangan hutan telah menyebabkan kekeruhan yang tinggi pada aliran sungai Digoel. Kekeruhan merupakan tingkat daya tembus cahaya dalam air yang dihasilkan oleh bahan padat tersuspensi (Reid dan Wood, 1976). Tingkat kekeruhan tertentu dapat membunuh jenis-jenis ikan yang peka terhadap perubahan kondisi lingkungan.

Penduduk sudah mengenal penangkapan ikan di sungai menggunakan racun sianida. Racun ini biasanya dalam bentuk bubuk Natrium Sianida, yang merupakan racun bereaksi cepat. Cara penangkapan ikan sangat berpotensi merusak sumberdaya perikanan, terutama benih ikan dan ikan-ikan yang peka terhadap perobahan kualitas air sungai, yang mengarah pada kepunahan stok.

Oleh karena itu, tindakan konservasi terhadap sumberdaya perikanan air tawar Kabupaten Boven Digoel perlu mendapat perhatian, yaitu suatu upaya perlindungan dan pengelolaan yang hati-hati terhadap lingkungan dan sumberdaya alamnya (Reif dan Levy, 1993).

Upaya pelestarian sumberdaya perikanan air tawar aliran sungai Digoel dapat dilakukan dengan pengaturan wilayah pemanfaatan aliran sungai Digoel, terutama daerah-daerah tempat berlindung dan bertelur ikan. Daerah-daerah ini merupakan 
daerah teluk yang tenang, yang disebut Pulau Ikan, yakni bagian sungai yang memiliki teluk yang terbuka ke arah tepi sungai, yang merupakan tempat beruaya ikan-ikan pada saat air sungai meluap untuk mencegah terbawa arus sungai ke bagian muara dan menghindari kekeruhan air sungai yang tinggi. Menurut penduduk setempat, ikan-ikan yang tertangkap di daerah ini umumnya berukuran besar dan membawa telur. Beberapa jenis ikan, seperti ikan mas dan gourame, memerlukan tempat yang tenang untuk meletakkan telurnya. Ikan mas biasanya menempelkan telur-telurnya pada akar-akar dan batang tumbuhan dalam air, sedangkan ikan gourame akan membuat sarang untuk peletakan telurnya sehingga daerah-daerah ini merupakan pilihan bagi jenis-jenis ikan yang memiliki tingkahlaku semacam ini. Namun demikian, intensitas pengoperasian jaring ikan di daerah ini sangat tinggi. Para penangkap ikan cukup memukul-mukul permukaan air untuk mengusir gerombolan ikan ke arah jaring insang yang dipasang. Hal ini dapat berpotensi mempercepat terjadinya degradasi stok ikan di aliran sungai Digoel, sehingga langkah-langkah pengaturan penggunaan jenis alat tangkap di daerah ini perlu diperhatikan.

Beberapa bagian sungai, yang diberlakukan hukum adat, dikuasai oleh orang tertentu yang disebut Tuan Dusun. Setiap orang yang memasuki wilayah ini harus mendapat izin Tuan Dusun. Sistem pengawasan tradisional ini merupakan suatu sistem perlindungan sumberdaya alam yang sangat efektif. Namun demikian, pengetahuan tradisional tentang ketersediaan sumberdaya perikanan dan langkahlangkah pemanfaatannya belum cukup untuk menjamin kelestarian sumberdaya ini di masa datang, sehingga membutuhkan langkah-langkah pembinaan masyarakat pesisir tentang prinsip-prinsip konservasi, dan untuk hal ini, pemerintah, atas nama masyarakat secara keseluruhan perlu memberikan subsidi positif (Bianchi dan Skjoldal, 2008). Misalnya, sumberdaya ikan yang memilki pemijahan musiman, seperti jenis ikan koloso atau sering dikenal sebagai ikan arwana. Jenis ikan ini merupakan jenis ikan purba dari famili Osteoglossidae (Allen, 1991) dan memiliki nilai ekonomis yang sangat tinggi sebagai ikan hias, sehingga eksploitasi yang lestari perlu diterapkan sesuai dengan sifat biologinya. Beberapa jenis kakap air tawar juga merupakan sumberdaya perikanan yang sangat potensial dalam memberi kontribusi pada hasil perikanan air tawar. Karena informasi tentang aspek biologi jenis ikan ini belum banyak tersedia, maka pengaturan tentang pemanfaatan sumberdaya perikanan ini tidak jelas dan memerlukan penelusuran informasi yang lebih mendalam.

\section{KESIMPULAN}

Dalam menunjang pemanfaatan sumberdaya perikanan yang lestari, tindakan perlindungan harus dilakukan dalam kaitan dengan penggunaan jenis alat penangkapan, perlindungan habitat ikan dan daerah pemijahannya, serta perlindungan terhadap stok ikan pada musim pemijahannya. Oleh karena itu, daerah aliran sungai Digoel perlu ditata kembali sesuai dengan peruntukkannya, seperti daerah penangkapan, budidaya dan daerah perlindungan, agar siklus biologi sumberdaya perikanan daerah aliran sungai tidak terganggu.

\section{DAFTAR PUSTAKA}

Allen, G.R. (1991). Freshwater f Fishes of New Guinea, Cristensen Research Institute, Madang Papua New Guinea. 268 hal.

Anonymous, 2006. Pembesaran Ikan Di Kolam Air Deras. Kiat Mengatasi Masalah Praktis. Tim Lantera. 96 hal. 
Anonymous, 2006. Nila Pospektif Dalam dan Luar Negeri. Direktorat Pemasaran Dalam Negeri. Direktorat Pengolahan dan Pemasaran Hasil Perikanan Departement kelautan dan Perikanan. Edisi Oktober 2006. Hal. 5.

Anonymous, 2007. Boven Digoel Dalam Angka. Kerjasama BAPPEDA abupaten Boven Digoel dengan BPS Kabupaten Boven Digpel. 228 hal.

Anonymous, 2008. Boven Digoel Dalam Angka. Kerjasama BAPPEDA abupaten Boven Digoel dengan BPS Kabupaten Boven Digpel. 245 hal.

Bahri, S., 2005. Teknik Penangkapan Udang Galah (Macrobrachium rosenbergii) Di Perairan Sungai Musi Bagian Selatan. Bull. Teknik Litkayasa Sumberdaya dan Penangkapan. Vol. 3. Hal. 15-17.

Bardach, J.E., J.H. Ryther, and W.O. Mclarney, 1972. Aguculture. The Farming and Hunbandary of Freshwater and Marine Organisms. John Wiley \& Sons, Inc. 868 hal.

Bianchi, G. and H.R. Skjoldal (ed.), 2008. The Ecosystem Approach To Fisheries. FAO, UN. 363 hal.

Hall, P.M., 1989. Variation in Geographic Isolates of the New Guinea crocodile (Crocodylus novaeguineae) Compared With The Similar, Allopatric Philippine Crocodile (C. mindorensis Schmidt). Copeia 1989(1): 70-80.

Huet, M., 1970. Texbook of fosh Culture: Breeding and Cultivation of Fish. England. 436 hal.

Iskandar, D.T., 2000. Kura-Kura dan Buaya Indoensia dan Papua Ngini. Penerbit ITB Bandung. 155 hal.

Karim, M., 2009. Potensi Budidaya Ikan Dari Jenis Perikanan Darat. Fak. Pertanian, Perikanan dan Biologi. Univ. Negeri Bangka Belitung. 2 hal.

Kottelat.M., A.J.Whitten, S.N.Kartikasari dan S.Wijoatmodjo (1993). Freshwater Fishes of Western Indonesia and Sulawesi. Perpilus Edition Limited, Jakarta, 293 hal.

Mumpuni, 2001. Reptilia. dalam M. Noerdjito dan I. Maryanto (eds.). Jenis-Jenis Hayati Yang Dilindungi Perundang-undangan Indonesia. Puslit Biologi LIPI-TNC-USAID, Bogor, hal. 112.

Reif, J.A. dan Levy, Y., 1993. Password: Kamus Bahasa Inggeris Untuk Pelajar Kesaint Blanc Indah Corp, Bekasi.

Mampioper, D.A., 2007. Kabar Indonesia: Ikan Gabus Aslu Danau Sentani Terancam Punah. Lingkungan Hidup. 2 hal.

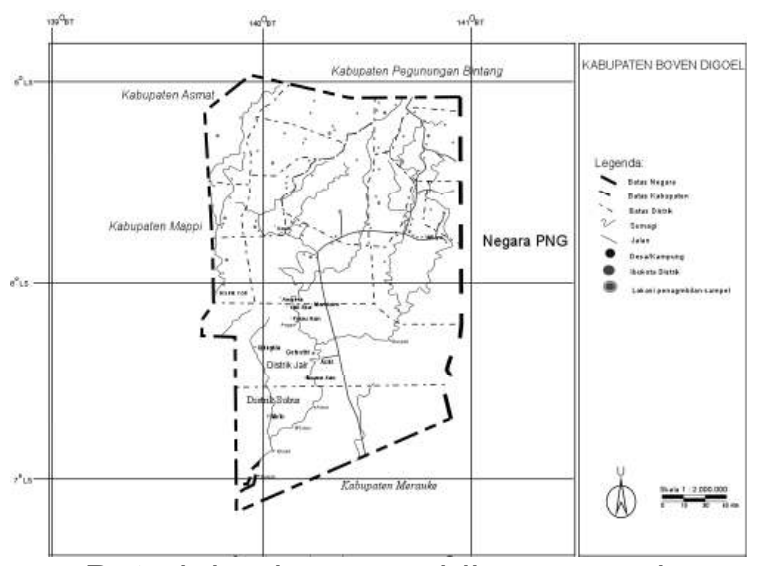

Peta lokasi pengambilan sampel. 